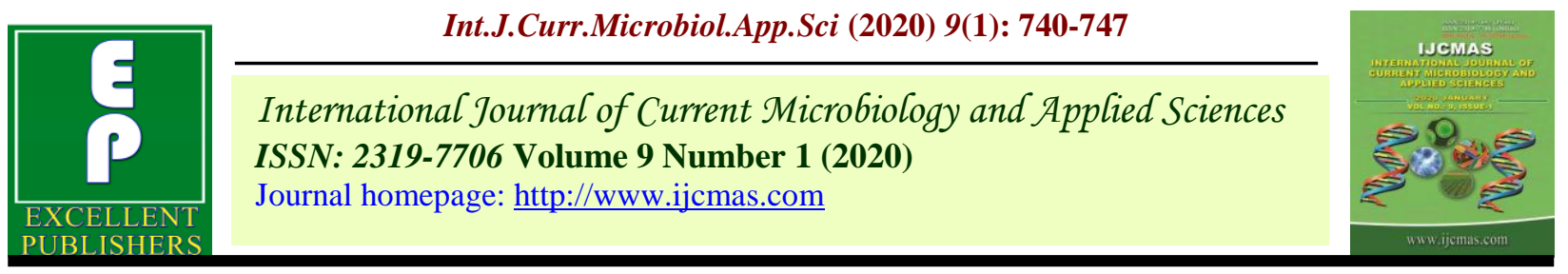

Original Research Article

https://doi.org/10.20546/ijcmas.2020.901.081

\title{
Temperature Adaptability and Disease Development Potentiality of Multi-Generation Isolates of Sclerotium rolfsii
}

\author{
Ritesh Kumar $^{1,2} *$, Abhijeet Ghatak ${ }^{1}$ and A.P. Bhagat ${ }^{1}$ \\ ${ }^{1}$ Department of Plant Pathology, Bihar Agricultural University, Sabour, \\ Bhagalpur, Bihar, India \\ ${ }^{2}$ Department of Plant Pathology, Bidhan Chandra Krishi Vishwavidyalaya, Mohanpur, \\ Nadia, West Bengal, India \\ *Corresponding author
}

\begin{tabular}{l} 
K e y w o r d s \\
$\begin{array}{l}\text { Collar rot, Disease, } \\
\text { elevated } \\
\text { temperature, } \\
\text { Sclerotium rolfsii, } \\
\text { Temperature } \\
\text { adaptability } \\
\text { Article Info } \\
\text { Accepted: } \\
\text { 15 December } 2019 \\
\text { Available Online: } \\
\text { 20January } 2020\end{array}$ \\
\hline
\end{tabular}

A B S T R A C T

Sclerotium rolfsii, obtained from cucumber roots, grew up to 20 generations at $25^{\circ} \mathrm{C}$ and at $35^{\circ} \mathrm{C}$ to assess the effect of enhanced temperature on the growth pattern of the fungus. At $25^{\circ} \mathrm{C}$, the isolates of early generations covered the entire plate $(90 \mathrm{~mm})$ on $120 \mathrm{~h}$ after inoculation. However, after the $8^{\text {th }}$ generation, due to repeated isolation and inoculation, reduced mycelium growth observed and almost ceased after the $16^{\text {th }}$ generation. At $35^{\circ} \mathrm{C}$, the mycelium started to be visible after $96 \mathrm{~h}$ of inoculation but the growth found to be meagre. At this incubation temperature, mycelium attended the progress after $5^{\text {th }}$ generation; a similar response noticed for the $5^{\text {th }}$ to $15^{\text {th }}$-generation isolates. The adaptability in the growth of this fungus towards higher temperature shows its potential to survive in the changing environment as a result of climate change. Further, the comparison of pathogenicity between the $1^{\text {st }}$ and $20^{\text {th }}$ generation isolates was tested on moong (Vigna radiata). Across varieties, no effect of $1^{\text {st }}$ generation-and $20^{\text {th }}$ generation-isolate on collar rot disease development was noticed. But yielding a similar amount of disease by the $20^{\text {th }}$ generation-isolate, which is resistant to elevated temperature, is indicating to take caution that should be implemented in future to make strategies against $S$. rolfsii.

\section{Introduction}

Sclerotium rolfsii causing collar rot is a wellknown, non-target pathogen having wide host range. It is among one of the most disparaging soil inhabiting pathogens and causing significant loss in several crops. The fungus is predominantly distributed in subtropical and tropical countries. It is common where temperature arises during the rainy season. 
Environmental condition of an area influences the growth of pathogen and hence the resulting losses (Elad and Pertot, 2014). Previous literature suggests that the optimal germination, growth and sclerotia production of the fungus is best suited at $25^{\circ} \mathrm{C}$ (Lin et al., 2009). Increase in temperature leads to change in shape and size of sclerotia but not complete discontinuation in the formation of this resting structure. In California, this pathogen may remain active at relatively higher temperatures of $27^{\circ} \mathrm{C}-32^{\circ} \mathrm{C}$ (Browne et al., 2002). In Tunisia, the ideal growth can be seen at $30^{\circ} \mathrm{C}-35^{\circ} \mathrm{C}$ (Daami-Remadiet al., 2010). The fungus $S$. rolfsii exhibits invariable change in mycelial growth at $25^{\circ} \mathrm{C}$. Hence, there is a possibility for adaptation of this pathogen to increased temperature regime $\left(35^{\circ} \mathrm{C}\right)$. This could be correlated with possibilities to increase in aggressiveness of this pathogen in the coming decades with higher mean global temperature. The influence of increased temperature due to climate change, on plant disease is hazardous to be through both the host plant and the pathogen (Coakley et al., 1999; Garrett et al., 2006). Climate change in terms of enhancing global temperature will change the pattern of disease by changes in host distribution and phenology, changes in microflora of host and direct biological effects on rapidly adjusting pathogens. An increase in the average annual temperature by $3^{\circ} \mathrm{C}$ is expected over the next coming century. Atmospheric $\mathrm{CO}_{2}$, a major greenhouse gas, has increased by nearly $30 \%$ and temperature has risen by 0.3 to $0.6^{\circ} \mathrm{C}$ (Chakraborty, 1998). Plant disease dynamic resulting due to this long term environmental conditions are less studied as the emphasis is considered towards the urgency of problems related to plant diseases. Assessment of the limited literature in this area proposes that the most likely impression of climate change will be felt in three areas: in losses from plant diseases, in the efficacy of disease management strategies and in the geographical distribution of plant diseases. There may be positive, negative or no impact on individual plant diseases due to change in temperature. The increase in temperature, as an outcome of climate change alters the behavior of both host plant and the pathogen. Adaptability of $S$. rolfsiito changing environmental conditions such as high temperature regimes are important to study.

\section{Materials and Methods}

This is an extensive work of our previous attempt (Kumar et al., 2017). The fungus was sampled from infected cucumber root, Agricultural Farm of Bihar Agricultural University, Sabour. The infected plant was taken to the laboratory, washed properly under flow of water, cut into small piece of $5 \mathrm{~mm}$ which include both infected and healthy portion. The segment was then surface sterilized by $1 \%$ sodium hypochloride for 2 min and rinsed in sterile distilled water thrice. The segment was allowed to grow on PDA (potato, dextrose, agar: $200 \mathrm{~g}, 20 \mathrm{~g}, 20 \mathrm{~g}$ in 1liter water) media supplemented with streptocycline antibiotic to check any type of bacterial growth at $25 \pm 1^{\circ} \mathrm{C}$ for 7 days. The fungal mycelia were took aseptically by inoculation loop and transferred to PDA slant for pure culture of the fungus. The pure isolate was identified on the basis of various characteristics (Sarma et al., 2002). The pathogen wassubjected to grow undertwo different incubation temperatures i.e. $25^{\circ} \mathrm{C}$ and $35^{\circ} \mathrm{C}$. A disc of actively growing mycelium was placed at the center of petriplate and cultivated for $120 \mathrm{~h}$ (at $25^{\circ} \mathrm{C}$ ) when the mycelium touched the periphery of the plate (Muthukumar and Venkatesh, 2013). The mycelium was re-isolated up to 20 generations. Four replicates for each temperature regime in a generation were adjusted following a complete randomized design (Gomez and Gomez, 1984) and the whole experiment was repeated twice. The 
comparison of fungal growth rate was made between $25^{\circ} \mathrm{C}$ and $35^{\circ} \mathrm{C}$ for the acclimatization of the pathogen in successive generations in response to climate change in the form of increased temperature.

An experiment on artificial inoculation was conducted to study the disease development potentiality of the pathogen using isolates of two generations $\left(1^{\text {st }}\right.$ and $\left.20^{\text {th }}\right)$. For that, the assessment of collar rot disease in moong (Vigna radiata) was done after growing in root trainer under open condition during middle February to April of 2019. The garden soil was previously subjected to double autoclaved in polypropylene bag containing $1.5 \mathrm{~kg}$ soil in order to eliminate the effect of any other soil-borne microorganism. Root trainers were filled-up with the sterilized soil mixed with the sclerotia of Sclerotiumrolfsii isolates at the rate of 100 sclerotia per $100 \mathrm{~g}$ of soil (Yaqub and Shahjad, 2005). Sowing was done using 4 different popular varieties viz. Samrat, Pusa Vishal, Hum-16 and Meha. The experiment was repeated twice. The experiment was conducted in Complete Randomized Design (Gomez and Gomez, 1984) involving 5 replications. Two root trainers (total 24 plants) were considered for each replication.

\section{Results and Discussion}

Effect of two different temperatures on the growth pattern of Sclerotium rolfsii and its pathogenicity in the successive twenty generations obtained by sub-culturing was assessed.

\section{Alteration in the growth pattern of Sclerotium rolfsii during successive generation}

The percent change in mycelial growth of the pathogen was found to be in increasing order (increase in mycelial growth than the previous generation) ata higher temperature $\left(35^{\circ} \mathrm{C}\right.$; figure 1).A reverse trend was observed at $25^{\circ} \mathrm{C}$. A decrease in mycelial growth than the previous generation was noticed at $25^{\circ} \mathrm{C}$. Up to 5 generations, no change in the growth pattern of mycelia was observed as compared to the previous generation at $25^{\circ} \mathrm{C}$. After $5^{\text {th }}$ generation, retardation in the percent change of mycelial growth was seen after $120 \mathrm{~h}$. This change was more prominently seen in a negative direction after $10^{\text {th }}$ generation and a similar difference was observed after $15^{\text {th }}$ generation. At a higher temperature of $35^{\circ} \mathrm{C}$, a slight increment in the percent change in mycelial growth was observed up to $15^{\text {th }}$ generation, but a large positive raise was observed after $15^{\text {th }}$ generation (figure 1). The change was found to be significant $(p \leq 0.001)$ after $16^{\text {th }}$ generation at $35^{\circ} \mathrm{C}$.

At $25^{\circ} \mathrm{C}$, the radial growth in the first generation started after $24 \mathrm{~h}$ and the full plate growth was seen after $120 \mathrm{~h}$. After frequent sub-culturing i.e. growth of the pathogen generation after generation at the same temperature, it was observed that in the $20^{\text {th }}$ generation reduced radial growth was noticed after $24 \mathrm{~h}$ as compared to the radial growth after $24 \mathrm{~h}$ in the first generation (figure 2). At $35^{\circ} \mathrm{C}$, the radial growth in first-generation was seen only after $72 \mathrm{~h}$. Nearly $20 \mathrm{~mm}$ radial growth was observed after $120 \mathrm{~h}$. At higher temperature i.e. $35^{\circ} \mathrm{C}$, in the $20^{\text {th }}$ generation, the radial growth at $96 \mathrm{~h}$ was found to be more than as seen in the first generation and the same trend was seen after $20^{\text {th }}$ generation at $120 \mathrm{~h}$. It is just reverse to that of $25^{\circ} \mathrm{C}$ (figure 2). At optimum of $25^{\circ} \mathrm{C}$, after successive sub-culturing, generation after generation the growth of pathogen was found to be in a retarding manner but at the higher temperature, the growth was found to be in an increasing mode. This shows the adaptability for the survival of the pathogen at higher temperature and changes at their optimum temperature. Plant pathogens have three 
general possibilities related to adapt to a changing environment: (i) exploit the present phenotypic plasticity, (ii) migrate to areas with a suitable climate, and/or (iii) evolve new characteristics (Oliva et al., 1993). Plant pathogens can grow and reproduce across a wide range of temperatures and can tolerate large thermal variations in different environments. Correlation can be made between the increased global temperature and impact on the disease caused by this fungus. Climate change presents considerable challenges for plant disease management (Garrett et al., 2006). While the particular effects of climate change on plant diseases will depend on the plant-pathogen system. The impact changes, such as temperature can be predicted for several plant species from empirical studies (Coakley et al., 1999).

\section{Invariable mycelial growth at different temperatures}

To estimate the impact of temperature on growth of $S$. rolfsii, the fungal isolate was grown on PDA and radial growth of mycelium was observed on 24, 48, 72, 96 and $120 \mathrm{~h}$ after inoculation (hai) at two different regimes of temperature i.e. $25^{\circ} \mathrm{C}$ and $35^{\circ} \mathrm{C}$. In general, the pathogen grew at $25^{\circ} \mathrm{C}$ and touched the periphery of the petriplate ( 90 $\mathrm{mm}$ ) on $120 \mathrm{~h}$. At $25^{\circ} \mathrm{C}$, no mycelial growth was recognized up to $24 \mathrm{~h}$; the visible growth of the fungus was observed on $48 \mathrm{~h}$ and completely filled the petriplate on $120 \mathrm{~h}$. The fungal growth measured on $72 \mathrm{~h}$ incubation was double of the growth taken on $48 \mathrm{~h}$ incubation. While the $96 \mathrm{~h}$ incubated petriplates rendered 1.5 times increase of mycelial growth over $72 \mathrm{~h}$ incubated petriplates. Similarly, the $120 \mathrm{~h}$ incubated petriplates had nearly 1.2 times progress of mycelium than $96 \mathrm{~h}$ (figure 2), which is in support with the earlier work done by Kumar et al., 2017. A reduction in fungal growth was observed starting from the $8^{\text {th }}$ generation at $25^{\circ} \mathrm{C}$. A significant difference in the growth reduction was recorded for incubation period $48 \mathrm{~h}, 72 \mathrm{~h}$ and $96 \mathrm{~h}$. However, at the $16^{\text {th }}$ generation, a meagre reduction in the growth of mycelium was detected; on $120 \mathrm{~h}$ the mycelial growth was restricted to $87 \mathrm{~mm}$, which was $90 \mathrm{~mm}$ in the isolate of $1^{\text {st }}$ generation (figure 2). This is indicating that the growth of the fungus is invariable to this temperature regime.

Lower fungal growth was recorded for high incubation temperature in initial generations. At $35^{\circ} \mathrm{C}$, no mycelial progress was observed even after $72 \mathrm{~h}$ of incubation at initial generations (figure 2). Even after $96 \mathrm{~h}$ incubation, poor growth $(<10 \mathrm{~mm})$ was noted and app. $20 \mathrm{~mm}$ growth was observed after $120 \mathrm{~h}$. Up to $4^{\text {th }}$ generation, the fungal growth was just double when the comparison was made with the two incubation period of $96 \mathrm{~h}$ and $120 \mathrm{~h}$. The $5^{\text {th }}$ and $6^{\text {th }}$ generation envisaged with the progress of approximately 2.5 times of fungal growth at $120 \mathrm{~h}$ than the growth at $96 \mathrm{~h}$ (figure 2). In the isolates of successive generation, the mycelial growth was recorded higher at the incubation period of $96 \mathrm{~h}$ and simultaneously at $120 \mathrm{~h}$. At higher temperature, an increase in the trend of mycelial growth was detected onward to $5^{\text {th }}$ generation (figure 1). This could interpret with the adaptability of $S$. rolfsiito increased temperature regime $\left(35^{\circ} \mathrm{C}\right)$. Temperature and generations both had significant $(p \leq 0.001)$ role in the changing of normal growth trend of the pathogen and adaptability to the new environment i.e. higher temperature regime. Adaptation to higher temperatures results mainly from genetic differentiation between populations (Zhang et al., 2011), but the presence of widespread plasticity in response to thermal extremes in these fungal pathogens suggest that the lack of genetic variation will not necessarily limit species distribution under climate warming. Adaptive plasticity may also contribute directly to species 
intrusiveness by allowing rapid colonization of diverse new hosts without the need to undergo the local selection (Williams et al., 1995). Individual plasticity may have an impact on the patterns of evolutionary diversification at the population (and ultimately species) level by excluding selective deviation in environmentally distinct sites (Sultan and Spencer, 2002).

Pathogenicity of $1^{\text {st }}$ and $20^{\text {th }}$ generation isolates of Sclerotium rolfsii

The pathogenicity of $S$. rolfsii isolates of $1^{\text {st }}$ and $20^{\text {th }}$ generation were assessed using four popular moong varieties viz. Samrat, Pusa Vishal, Hum-16 and Meha. S. rolfsii epidemics initiated in the root trainers by artificial inoculation (Yaqub and Shahjad, 2005). Disease incidence (DI) was recorded in moong after inoculation of $S$. rolfsii isolates of $1^{\text {st }}$ and $20^{\text {th }}$ generations as suggested by Ghatak et al., 2010. An isolate of $1^{\text {st }}$ generation of the pathogen showed highest DI observed in Meha followed by Samrat, Pusa Vishal and Hum-16. From table 1, it can be noticed that DI caused by the isolate of $20^{\text {th }}$ generation in the first experiment also rendered a similar trend and the difference in
DI caused by the isolate of $1^{\text {st }}$ generation and $20^{\text {th }}$ generation was found to be nonsignificant $(p \geq 0.001)$. After several subculturing, even the virulent isolates loss their degree of pathogenicity (Ansari and Butt, 2011; Eslami et al., 2015; Sultana et al., 2018); the property is known as attenuation.

The presence of virulence in the isolate assistsin survival and the non-virulent ones are reduced or eliminated with each reinoculation (Agrios, 2005). In this study, the isolate showed nearly no difference in its pathogenicity (disease development) whether it has been used after $19^{\text {th }}$ sub-culturing. This shows the high degree of adaptability and virulent nature of the isolate. The adaptivebehaviour towards high temperature as seen in the form of changes in radial growth from generation 1 to 20 at two different temperature regimes has an impact on the diseases caused by this fungus, as indicated in producing DI (table 1). Several aspects of the biology of a pathogen can be directly influenced by changing environmental factors (Ghatak and Ansar, 2017; Vati and Ghatak, 2015).

Table.1 Comparison between $1^{\text {st }}$ and $20^{\text {th }}$ generation isolates of Sclerotium rolfsiifor disease incidence in moong varieties

\begin{tabular}{|l|l|l|l|l|}
\hline \multirow{2}{*}{$\begin{array}{l}\text { Moong } \\
\text { varieties }\end{array}$} & Experiment 1 & \multicolumn{2}{l|}{ Experiment 2 } \\
\cline { 2 - 5 } & Generation 1 & Generation 20 & Generation 1 & Generation 20 \\
\hline Samrat & $22.0( \pm 2.8)$ & $23.2( \pm 1.1)$ & $21.9( \pm 2.3)$ & $21.1( \pm 0.9)$ \\
\hline Pusa Vishal & $21.1( \pm 1.3)$ & $19.6( \pm 2.0)$ & $20.5( \pm 2.0)$ & $19.9( \pm 1.0)$ \\
\hline Hum-16 & $10.8( \pm 1.3)$ & $11.2( \pm 1.1)$ & $11.5( \pm 0.9)$ & $12.3( \pm 2.7)$ \\
\hline Meha & $29.4( \pm 3.7)$ & $28.9( \pm 1.7)$ & $28.9( \pm 1.8)$ & $29.0( \pm 1.0)$ \\
\hline
\end{tabular}

The values inside the parentheses are the standard error of the mean. 
Figure.1Percent change in radial growth $(\mathrm{mm})$ of Sclerotium rolfsiiin successive twenty generations. Bars of particular temperature with similar letter are not significantly different according to Duncan's multiple range test at $p \leq 0.001$

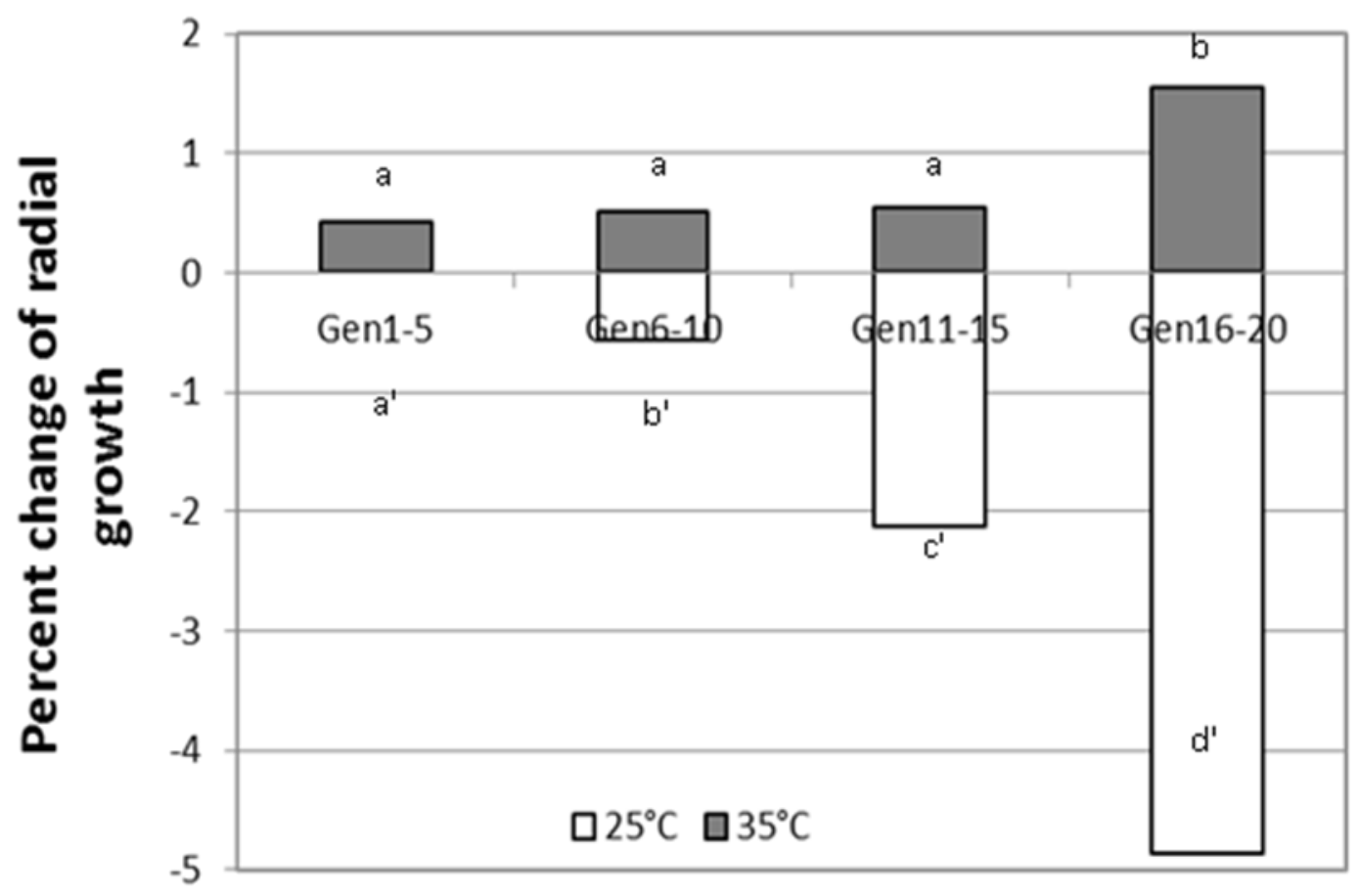

Figure.2: Variation in mycelial growth at different time intervals in two generations. Gen1: generation $1^{\text {st }}$ and Gen20: generation $20^{\text {th }}$

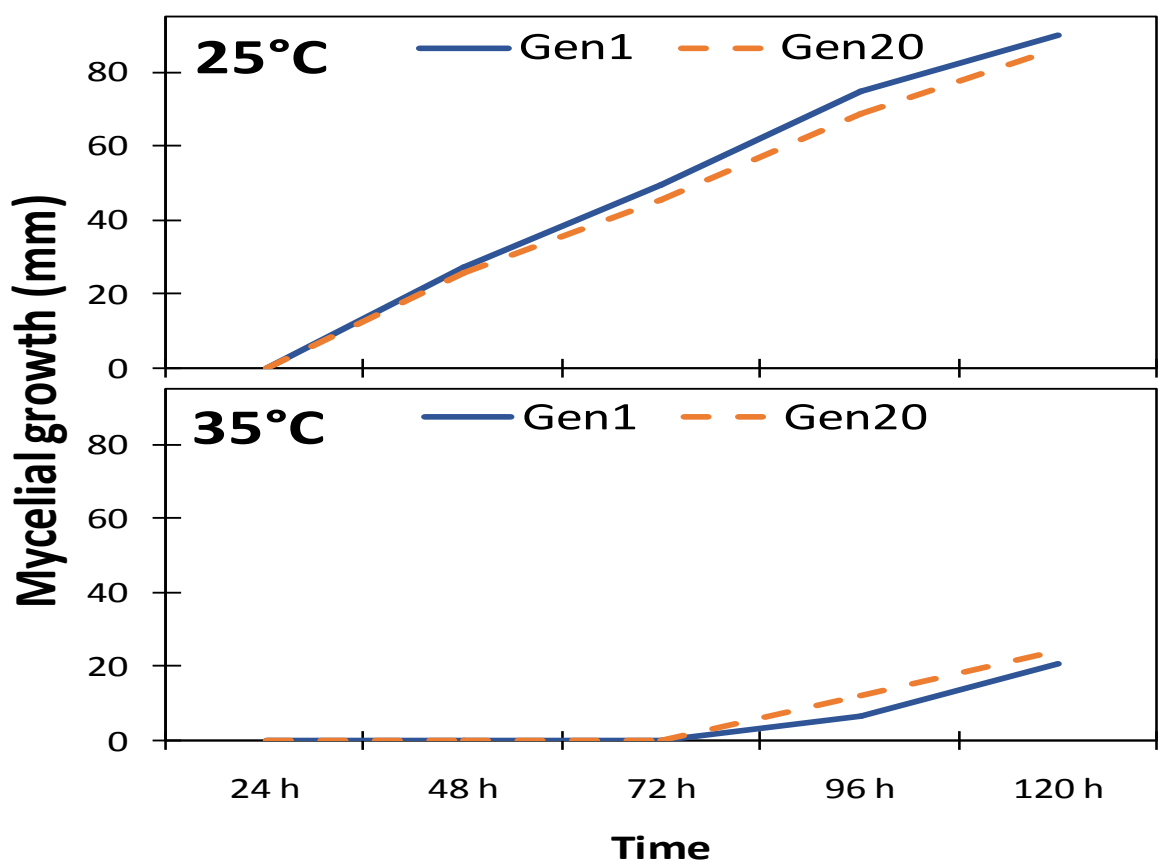


Continue exposure to an environmental condition like the temperature at its optimum for the development of the pathogen leads to increase in severity of disease-causing ability and hence to high epidemics. With a rise in the duration of ideal temperature, many pathogens spread in a new manner and infect the new hosts in the region. The temperature, in particular, has a primary role in the interaction between pathogen and their hosts, affecting epidemic outbursts and co-evolution processes. Also, some other traits at gene level may be present in the adapting strains of S. rolfsii.

In conclusion, at the preliminary stage, the present study unveiled another facet of this fungus. This information opens a scope for further studies considering the temperature adaptability with an increased number of generations. Each pathogen has got its own cardinal temperature and understanding the temperature of the pathogen will help to standardize the management practices. But the adaptability of the pathogens towards higher temperature in the arena of global warming and climate change will disturb various models of crop protection so, from the management side, these needed to be upgraded regularly. The potential influence of global warming on a species will depend on its thermal reaction norm and the underlying genetic dissimilarity for temperature sensitivity in the affected populations (Zhang et al., 2011).

\section{References}

Agrios, G. N. (2005). Plant Pathology. Academic Press, ISBN: 9780080473789.

Ansari, M. A. and Butt T.M. (2011). Effects of successive subculturing on stability, virulence, conidial yield, germination and shelf-life of entomopathogenic fungi. Journal of Applied Microbiology,
110: 1460-1469.

Browne, G. T., De Tar, W. R., Sanden, B. I. and Phene, C. J. (2002). Comparison of drip and sprinkler irrigation systems for applying sodium and managing stem rot on potato. Plant Disease, 86: 12111218.

Chakraborty, S. (1998). Potential impact of climate change on plant diseases of economic significance to Australia. Australasian Plant Pathology, 27: 1535.

Coakley, S. M., Scherm, H. and Chakraborty, S. (1999). Climate change and disease management. Annual Review of Phytopathology, 37: 399-426.

Daami-Remadi, M., Jabnoun-Khiareddine, H., Sdiri, A. and ElMahjoub, M. (2010). Effect of temperature on Sclerotium rolfsii mycelia growth and rot severity on potato tubers. African Journal of Biotechnology, 4: 54-58.

Elad, Y. and Pertot, I. (2014). Climate change impacts on plant pathogens and plant diseases. Journal of Crop Improvement, 28: 99-139.

Eslami, A. A., Khodaparast, S.A., Mousanejad, S., Dehkaei, F. P. (2015). Evaluation of the virulence of Sclerotium rolfsii isolates on Arachis hypogaea and screening for resistant genotypes in greenhouse conditions. Hellenic Plant Protection Journal, 8: 111.

Garrett, K., Dendy, S., Frank, E., Rouse, M. and Travers, S. (2006). Climate change effects on plant disease: genomes to ecosystems. Annual Review of Phytopathology, 44: 489-509.

Ghatak, A., and Ansar, M. 2017. The Phytopathogen: Evolution and Adaptation. Apple Academic Press, Taylor and Francis Group, USA. ISBN: 978-1-77188-406-8

Ghatak, A., Srivastava, J.S., and Vikram, P. 2010. Interactions of Sclerotium rolfsii 
with different isolates of Trichoderma and resulting changes in biomass and collar rot incidence in chickpea. Plant Disease Research, 25(1): 55-58.

Gomez, K. A. and Gomez, A. A. (1984). Statistical procedures for agricultural research. John Wiley and Sons, New York, 2: 680.

Kumar, R., Ghatak, A. and Bhagat, A.P. (2017). Exploration of Sclerotium rolfsii adapting high temperature regime in successive generation. Indian Journal of Ecology, 44 (Special Issue-5): 402-406.

Lin, M. A., Yin, F., Zeng, W. and Huang, Y. (2009). Biological characteristics of Sclerotium rolfsiiSacc. in Coptis chinensis and screening on its controlling fungicides. Journal of Anhui Agricultural Sciences, 34: 240-245.

Muthukumar, A. and Venkatesh, A. (2013). Effect of light and aeration on the growth of Sclerotium rolfsiiin vitro. African Journal of Biotechnology, 12 (49): 6843-6846.

Oliva, G., Martinez, A., Collants.,M. and Dubcovsky, J. (1993). Phenotypic plasticity and contrasting habitat colonization in Festuca pallascense. Canadian Journal of Botany, 71: 970971.

Saccardo, P. A. (1911). NotaeMycologiae. Annual Mycology, 9: 249-257.

Sarma, B. K., Singh, U. P. and Singh, K. P. (2002). Variability in Indian isolates of Sclerotium rolfsii. Mycologia, 94(6): 1051-1058.
Sultan, S. E. and Spencer, H. G. (2002). Meta population structure favors plasticity over local adaptation. American Naturalist, 160: 271-283.

Sultana, S., Adhikary, S. K., Islam, M. M., and Rahman S. M. M. (2018). Evaluation of pathogenic variability based on leaf blotch disease development components of Bipolaris sorokiniana in Triticum aestivum and agroclimatic origin. Plant Pathology Journal, 34(2): 93-103.

Vati, L., and Ghatak, A. (2015). Phytopathosystem modification in response to climate change. In: Climate Dynamics in Horticultural Science: Impact, Adaptation, and Mitigation; Choudhary, M. L., Patel, V. B., Siddiqui, M. W., Verma. R. B., Eds.; CRC Press: Florida : 161-178.

William, D. J., Mack, R. N. and Black, R. A. (1995). Ecophysiology of introduced Pennisetumsetaceum on Hawaii: the role of phenotypic plasticity. Ecology, 76: $1569-80$.

Yaqub, F. and Shahzad, S. (2005). Pathogencity of Sclerotium rolfsii on different crops and effect of inoculum density on colonization of mungbean and sunflower roots. Pakistan Journal of Botany, 37: 175-180.

Zhang, J. and Mc Donald, B. (2011). Thermal adaptation in fungal pathogen Mycospharella graminicola. Molecular Ecology, 20: 1689-1701.

\section{How to cite this article:}

Ritesh Kumar, AbhijeetGhatak and Bhagat, A.P. 2020. Temperature Adaptability and Disease Development Potentiality of Multi-Generation Isolates of Sclerotium rolfsii. Int.J.Curr.Microbiol.App.Sci. 9(01): 740-747. doi: https://doi.org/10.20546/ijcmas.2020.901.081 